Published in final edited form as:

Annu Rev Sociol. 2017 July ; 43: 379-404. doi:10.1146/annurev-soc-060116-053331.

\title{
WEALTH INEQUALITY AND ACCUMULATION
}

\author{
Alexandra Killewald, \\ Harvard University \\ Fabian T. Pfeffer, and \\ University of Michigan \\ Jared N. Schachner \\ Harvard University
}

\section{Abstract}

Research on wealth inequality and accumulation and the data upon which it relies have expanded substantially in the twenty-first century. While the field has experienced rapid growth, conceptual and methodological challenges remain. We begin by discussing two major unresolved methodological concerns facing wealth research: how to address challenges to causal inference posed by wealth's cumulative nature and how to operationalize net worth, given its highly skewed nature. To underscore the need for continued empirical attention to net worth, we review trends in wealth levels and inequality and evaluate wealth's distinctiveness as an indicator of social stratification. Next, we provide an overview of data sources available for wealth research. We then review recent empirical evidence on the effects of wealth on other social outcomes, as well as research on the determinants of wealth. We close with a list of promising avenues for future research on wealth, its causes, and its consequences.

In 2000, the Annual Review of Sociology (ARS) published two articles bringing sociologists' attention to wealth as a previously overlooked dimension of social inequality (Keister and Moller 2000; Spilerman 2000). Seventeen years later, the landscape of wealth inequality, wealth data, and wealth research has changed considerably. While scholars have resolved several concerns raised by Spilerman and Keister and Moller, the proliferation of data and research has raised new questions and highlighted the lack of consensus about basic modeling decisions. In many ways, then, the field has moved from its infancy to its adolescence: It has experienced tremendous growth and progress, but there is also substantial room for continued development, particularly in understanding wealth-generating processes.

In this article, we offer guidance to sociologists interested in studying wealth inequality and accumulation. We begin by highlighting conceptual and methodological challenges faced in analyzing wealth. Rather than treating these concerns as secondary to substantive findings, we consider them fundamental to the success of future research on wealth's causes and consequences. Next, we provide updated trends in levels and inequality of U.S. wealth 
through the Great Recession and document how closely related wealth is to a more common measure of socioeconomic status: income. In this section, we show that methodological decisions have implications even for a question as simple as the strength of the incomewealth association. We follow these analyses with a discussion of wealth data sources. Finally, with an eye to the methodological and conceptual challenges outlined in the first section, we review substantive evidence for the effects of wealth on other outcomes, as well as research on the determinants of wealth, emphasizing studies published since the 2000 ARS pieces.

Recent studies have centered on the increasing concentration of wealth at the very top of the distribution (Kopczuk \& Saez 2004, Saez \& Zucman 2016), including an $A R S$ article focused on the one percent (Keister 2014). This focus is reasonable, but here we emphasize that wealth is an important dimension of stratification not only for the ultra-wealthy but for a broader range of households. In other words, we conceptualize wealth not merely as an aspect of closure among economic elites but as a population-level phenomenon

\section{Part I: Conceptual and Methodological Challenges in the Analysis of Wealth Wealth as a Cumulative Measure}

Wealth is typically measured as net worth: the sum of the value of a household's assets, less the value of debts. While income measures the flow of financial resources at a particular time, wealth is a cumulative stock that reflects years of prior circumstances and decisions. This feature raises several analytic concerns, particularly with regard to causal inference. Causal claims linking wealth to another outcome are subject to variety of potential criticisms: Associations between parental wealth and offspring outcomes net of other parental socio-economic (SES) controls may merely capture spurious associations, including those due to measurement or specification error in the other SES variables. This concern is heightened if other predictors are point-in-time, given that wealth carries traces of prior experiences. For example, if offspring outcomes are affected by parental income throughout childhood, but parental income is measured in a single year, the association between parental wealth and offspring outcomes may merely reflect wealth's association with permanent income, net of current income. Averaging income measures across several preceding years, when possible, reduces this concern.

The cumulative nature of wealth has similar implications when it is the dependent variable. Scholars may wish to examine how wealth levels differ by race, gender, and social origins, and to what extent this variation is accounted for by other determinants of wealth, such as education and income. Typically, these latter determinants are measured only contemporaneously with wealth. For example, in examining the race gap in wealth, scholars frequently measure the gap unexplained by differences in current income levels, rather than the difference unexplained by differences in lifetime income streams to date. Again, averaging income over multiple years, when possible, can alleviate this concern. Although income is the most obvious variable with cumulative effects on wealth, other time-varying wealth determinants, such as marriage and neighborhood context, are subject to the same challenge. 
An alternative approach is to model wealth accumulation rather than net worth, using either lagged dependent variables or change models (e.g., Conley 2001a, Hurst et al. 1998, McKernan et al. 2014, O'Brien 2012). The advantage is that, rather than requiring lifetime histories of relevant covariates, fewer data points may suffice; characteristics in one period (including wealth) may approximate the relevant set of factors determining wealth gain or loss achieved by the next period.

Wealth's status as a cumulative measure becomes even more problematic in the presence of reverse causality concerns. Marriage, health, residential selection, homeownership, selfemployment, and portfolio composition are all characteristics that may both be shaped by prior wealth and shape subsequent wealth. Panel methods estimating within-individual change can help to alleviate reverse causality concerns. Alternatively, macro-economic fluctuations can serve as exogenous shocks facilitating identification of wealth effects on various outcomes. For example, Lovenheim and Reynolds (2013) exploit exogenous variation across Metropolitan Statistical Areas (MSAs) in trends in housing values to estimate the effects of parental home appreciation on offspring college attendance, choice, and completion. Still, these methods are not a panacea. For example, first-difference models might estimate the short-term wealth consequences of unemployment or health shocks, but they cannot reveal how chronic exposure to unemployment or illness cumulatively affect accumulated wealth in later life: narrowing the time window comes at the expense of fully capturing early life experiences' downstream wealth effects. An alternative is marginal structural models, estimated with inverse probability of treatment weights, which offer one way to model dynamic selection processes over time (Robins et al. 2000). Killewald and Bryan (2016) use this approach to estimate the long-term wealth consequences of time spent in homeownership.

The difficulty of establishing causal relationships has complicated assessments of the processes by which wealth accumulation occurs and between-group disparities in wealth arise. In the third section, we elaborate on our belief that future research must seriously engage the methodological challenges posed by wealth's cumulative nature in order to advance sociologists' understanding of the causes and consequences of wealth inequality. As described in a later section, advances in data availability, especially in long-term panel studies, support this endeavor.

\section{Operationalizing an Error-Prone, Highly-Skewed Variable}

Scholars interested in studying wealth's determinants or estimating the magnitude of between-group disparities in net worth face a seemingly straightforward question: how should net worth be operationalized? So far, there is no consensus on best practices. Given measurement error concerns, wealth measures would ideally be averaged across several years to reduce attenuation bias when used as a predictor variable. However, this approach requires measures of wealth at multiple points, which are not always available.

A second problem is that the wealth distribution is highly right-skewed. Minimally, topcoding net worth values can help reduce the potential for unduly influential outliers. Using median regression, rather than conditional mean models like ordinary least squares, also reduces the sensitivity of results to extreme observations. Another common solution is to 
log-transform net worth, but this approach requires a decision about how to treat zero and negative values. When wealth is an independent variable, these values may be incorporated with dummy variables indicating negative or zero net worth, or with a separate variable measuring log net debt. When wealth is the dependent variable, there is no straightforward solution, but some common strategies are to convert all negative values to a small positive value, to shift all values up by a sufficient amount that the entire range is positive (a "started log"), or to simply exclude non-positive values. Recoding negative values to a small positive value obscures relative net debt values and creates an outlier mass point at the low end of the log net worth distribution (Friedline et al. 2015), so we advise against it. An alternative is the inverse hyperbolic sine (IHS) transformation, which can incorporate zero and negative values, generating a function that is approximately linear close to zero and approximates the logarithm for large values (Friedline et al. 2015, Pence 2006).

The transformation selected has important implications for the assumed pattern of associations between other model predictors and net worth. The log-transform assumes that changes in the independent variables have (roughly) constant proportional effects on net worth, whereas the untransformed specification assumes additive effects. Wealth transformations are therefore not an incidental technical decision, but a conceptual choice with potential consequences for substantive conclusions. For instance, whether bequests increase wealth inequality (Boserup et al. 2016, Karagiannaki Forthcoming) and whether whites experience greater wealth benefits of homeownership than African-Americans and Hispanics (Killewald \& Bryan 2016) depend on whether comparisons are made in absolute or relative terms. Thus, scholars should justify their operationalization choices and consider whether substantive conclusions change with alternative transformations of net worth.

Recent research has begun to consider the possibility that both the consequences (e.g., Friedline et al. 2015, Killewald 2013) and the determinants of wealth vary across the wealth distribution (e.g. Addo \& Lichter 2013, Killewald 2013, Maroto 2016). When wealth is a predictor, we recommend experimenting with more flexible functional forms in order to identify a well-fitting specification. When wealth is the dependent variable, considering the possibility of variation in effects across the distribution is more complicated. We describe two analytic techniques can reveal such heterogeneity. The first, unconditional quantile regression, estimates how changes in independent variables are associated with changes in various quantiles of the outcome variable, net of control variables (Firpo et al. 2009, Killewald \& Bearak 2014). Maroto (2016) uses this approach to show that differences in education, employment, and income explain a greater share of whites' wealth advantage relative to African-Americans and Hispanics at the top of the wealth distribution than at the bottom. The second approach, pioneered by DiNardo, Fortin, and Lemieux (1996) for the study of wage distributions, offers a semiparametric method for reweighting distributions in order to simulate counterfactual scenarios. Sierminska et al. (2010) use this approach to simulate the wealth distribution for partnered women, if they had the same characteristics as partnered men. Given that wealth determinants may vary sharply across the wealth distribution, we encourage researchers to use these and other methods, rather than capture only mean differences. 


\section{PART II: Wealth Patterns and Data}

\section{Advances in Data Availability}

Over the last several decades, collecting net worth measures has become more common in large-scale surveys fielded in the U.S. and abroad. Although we recognize that our list may not be exhaustive, Table 2 describes over two dozen major surveys that permit the construction of a net worth measure. Many of the surveys are longitudinal and several cover multiple decades, allowing observation of wealth over a large portion of the life course and - for genealogical panel studies, such as the Panel Study of Income Dynamics (PSID) and its international sister studies - increasingly across generations. Several surveys, including the Survey of Consumer Finances (SCF) in the U.S., oversample the wealthy to improve description of the top of the wealth distribution. The Luxembourg Wealth Study (LWS), the Household Finance and Consumption Survey (HFCS), the Survey of Health, Ageing and Retirement in Europe (SHARE), and the International Social Survey Program (ISSP) are multinational datasets that facilitate comparisons across many Western countries, but the availability of wealth data is expanding even to transition and developing countries (Davies 2008).

Most surveys construct wealth as a household-level measure, although some treat the respondent and partner (if any) as the wealth-holding unit. One advantage of the latter approach is that it enables the calculation of personal wealth for young adults still living with their parents. In addition, the German Socio-Economic Panel (SOEP) collects asset information at the individual level, including proportional ownership of jointly-owned assets by couples, allowing separate wealth measures for each partner within couples.

Among U.S. datasets, the SCF collects the most detailed wealth information. As a consequence, it is often used as a benchmark to judge the validity of wealth data collected in other surveys. The PSID and Health and Retirement Survey (HRS) compare favorably to the SCF up until at least the $95^{\text {th }}$ percentile of the wealth distribution (Bosworth \& Smart 2009, Juster et al. 1999, Pfeffer et al. 2016), while the Survey of Income and Program Participation (SIPP) wealth data diverge more sharply (Curtin et al. 1989, Czajka et al. 2003).

Administrative data can supplement or substitute for survey data on net worth. For example, HRS matches survey data to administrative data from the Social Security Administration and employer-provided pension data to construct an augmented net worth measure capturing a broader range of resources available for future retirement (Hauser \& Weir 2010). Scandinavian administrative data sources are particularly powerful because they provide very high-quality wealth measures based on tax registers, often allowing the tracking of individuals across their life-course and across generations for the full population (e.g. Hällsten \& Pfeffer Forthcoming for Sweden, and Hansen 2014 for Norway). However, the phase-out of wealth taxation abolishes this data source for some countries, like Sweden since 2007.

\section{Trends in Wealth and Wealth Inequality}

Keister and Moller (2000) use data from the Survey of Consumer Finances and the 1962 Survey of the Financial Characteristics of Consumers to estimate trends in the average level 
and overall distribution of net worth from 1962 to 1995. In Table 1, we reproduce estimates from Pfeffer and Schoeni (2016) to describe trends from 1989 to 2013. The first panel shows trends in wealth levels, including mean and median household wealth in thousands of dollars; the remainder of the table shows various measures of net worth inequality. Inequality in net worth increased in the second half of the twentieth century (Keister \& Moller 2000), but more rapidly in the new millennium: Between 2001 and 2013, the wealth share owned by the top 1 percent increased from 32 to 36 percent. Inequality also increased throughout the distribution. The ratio of wealth held by households at the 95 th percentile relative to those at the median increased from 15:1 to 23:1 and, for households at the median relative to those at the $25^{\text {th }}$ percentile, from $7: 1$ to $9: 1$.

While inequality rose particularly rapidly during the Great Recession (Pfeffer et al. 2013, Wolff 2016), the trend persisted even as the official recovery began in 2009. The tremendous wealth destruction wrought by the recession has left the median U.S. household with less net worth in 2013 than in 1995 (\$81,400 vs. $\$ 87,700$ in 2013-\$). In contrast, mean wealth rose from $\$ 323,500$ to $\$ 528,400$ during the same time span, reflecting the disproportionate growth of wealth at the top as well as losses at the bottom: the share of households with no wealth or in net debt increased from $9.7 \%$ to $12.9 \% .^{1}$

Piketty's Capital in the Twenty-First Century (2014) reveals similar aggregate wealth trends throughout the developed world. Building on prior publications, Piketty shows that wealth inequality has followed a U-shaped trajectory across most developed countries since 1900, with the upswing occurring in the U.S. since about 1970 and in Europe since about 1980. Piketty traces the preceding declines in wealth inequality to war-induced asset devaluation, high tax rates, and skills investments spurring economic growth. He attributes the recent increase in wealth inequality to the rate of return to capital overtaking the economic growth rate (for critiques, see Acemoglu \& Robinson 2015, Soskice 2014). In this article, we focus primarily on the determinants and consequences of wealth in the United States. However, Piketty's (2014) findings show that developed countries have generally experienced similar trends in wealth inequality through the $20^{\text {th }}$ century, although inequality levels differ considerably.

\section{Wealth's Distinctiveness in Social Stratification}

While some social scientists view wealth merely as a less error-prone measure of lifetime (permanent) income, wealth scholars argue that family wealth and family income are conceptually distinct (Keister \& Moller 2000, Spilerman 2000). In recent decades, ample evidence has substantiated this assertion: as we describe later, wealth is associated with a host of outcomes, net of income. Given the theoretical centrality of the claim that wealth captures aspects of economic wellbeing distinct from income, the lack of a well-established wealth-income correlation estimate is surprising. The typically-cited estimate is based on an endnote in Lerman and Mikesell (1988) (cited in Keister and Moller 2000), which is thin on

\footnotetext{
${ }^{1}$ Most net worth measures exclude pension wealth ("augmented net worth"). Survey collection on pension wealth is difficult, as individuals struggle to estimate the value of their entitlements from pension plans and Social Security (Curtin et al. 1989, Ekerdt \& Hackney 2002). Pension wealth has transformed since the 1980s with the shift from defined benefit to defined contribution plans. This shift has not reduced mean retirement wealth, at least up to the Great Recession (Wolff 2011, 2015), but it has increased inequality in pension wealth and total wealth (Devlin-Foltz et al. 2016).
} 
empirical detail (see also Díaz-Giménez et al. 1997). To address this gap, we estimate Pearson correlation coefficients between total household net worth and total household income based on the Survey of Consumer Finances (SCF) and the Panel Study of Income Dynamics (PSID) for the most current available survey year, 2013, and the earliest year for which both surveys collected data, 1989. Using the PSID, we also approximate permanent income by averaging household income across a 10-year period of observed measurement (2003-2013 and 1979-1989), testing whether quasi-permanent income indeed closely tracks wealth. We report wealth-income correlations as they differ across datasets, variable transformations, age groups, periods, and income concepts to help wealth researchers understand the potential consequences of different modeling decisions in light of the concerns discussed in the previous section.

To demonstrate the results' sensitivity to different variable transformations, we estimated income-wealth correlations: (1) using raw values, (2) after top-coding both variables at the $99^{\text {th }}$ percentile to reduce the influence of outliers, (3) taking the natural logarithm of positive values to reduce skew (and excluding zero and negative values); (4) using the inverse hyperbolic sine transformation to achieve a similar transformation of positive net worth values as the $\log$ transformation and also to incorporate non-positive values; (5) using percentiles as an alternative way to reduce skew and incorporate the full range of values.

Our analysis (see Figure 1) reveals that correlations based on top-coding both variables at the $99^{\text {th }}$ percentile, taking the natural logarithm, or using percentiles yield similar estimates of about 0.6 - larger than those generated by raw measures or the inverse hyperbolic sine transformation. Wealth-income correlations are higher when drawing on multiple rather than single income year measures from the PSID. Thus, our results confirm that long-term income better approximates wealth than single-year income, but wealth remains distinct, even from long-term measures of income.

How does the wealth-income correlation vary across the life course and across time? Income and wealth are more weakly associated in young adulthood, underscoring wealth's cumulative nature (see Figure 2). Wealth and income have not become more aligned over time; in fact, the wealth-income correlation appears to have decreased over the last quarter century (see Figure 3). In the PSID, this trend also holds when we exclude asset income from the income measure. As expected, excluding asset income from household income reduces the wealth-income correlation but by less than previously thought (Figure 3): Keister and Moller (2000) cited a decline from approximately .50 to .26 by excluding asset income; we observe a drop in the SCF from .66 (1989) and .64 (2013) to above .50 in both years.

\section{Part III: Evidence on Wealth Consequences and Determinants Consequences of Wealth: Wealth as Predictor}

A substantial line of research has demonstrated that family wealth is associated with other social outcomes, above and beyond standard socio-economic and demographic predictors. Parental wealth is associated with greater offspring educational and cognitive achievement (Conley 1999, 2001b; Doren \& Grodsky 2016, Friedline et al. 2015, Jez 2014, Orr 2003, 
Pfeffer 2011, Yeung \& Conley 2008) and labor market outcomes, such as occupational attainment and work hours (Conley 1999, Pfeffer 2011). Parental wealth and home value appreciation are positively associated with college enrollment, institutional quality, and bachelor's degree completion (Conley 2001b, Doren \& Grodsky 2016, Jez 2014, Lovenheim \& Reynolds 2013), as well as transitions to homeownership (Charles \& Hurst 2002, Spilerman \& Wolff 2012).

Individuals' own wealth also speeds transitions to homeownership (Di \& Liu 2007, Killewald \& Bryan 2016) and facilitates self-employment (Fairlie \& Krashinsky 2012, but see also Hurst \& Lusardi 2004). For men, wealth encourages retirement (Conley \& Thompson 2013). In terms of family structure, young adults' own wealth supports marriage, while debt encourages cohabitation (Addo 2014, Schneider 2011). Among older, previouslymarried Americans, wealth accelerates both cohabitation and remarriage (Vespa 2012). For women, student debt is associated with fertility delay, while both mortgages and credit card debt accelerate transitions to parenthood (Nau et al. 2015).

Among older adults, wealth is negatively associated with mortality (Attanasio \& Hoynes 2000, Bond Huie et al. 2003) and positively associated with maintaining good health (Hurd \& Kapteyn 2003, Semyonov et al. 2013). Yet other scholars argue that the association between wealth and subsequent health changes or mortality is spurious (or nearly so) or specific to particular health conditions (Adams et al. 2003, Banks et al. 2010, Smith 2007). A challenge hampering evaluation of the association between wealth and health is that both are stock measures. While transitions to marriage and parenthood are point-in-time events, health outcomes, like wealth levels, reflect many years of prior influences. Therefore, the fact that wealth shocks do not immediately lead to health changes or increased mortality rates does not preclude the possibility that a lifetime of wealth conditions has a cumulative effect on health outcomes in older age. Consistent with this intuition, Adams et al. (2003) find that socioeconomic status is not associated with sudden-onset health conditions but is associated with gradual-onset conditions - as we would expect if wealth has a cumulative rather than immediate effect.

Wealth may affect the aforementioned outcomes for a host of reasons. Financial assets can buffer negative economic shocks. In old age, wealth may be a critical source of financial resources that replaces employment income. Real assets, such as vehicles and homes, have use value. Parental wealth may benefit children by shaping the quality of their neighborhood and school contexts, as well as the resources available at home. More directly, access to financial resources may ease the transition to adulthood by facilitating higher education, the purchase of a first home, or a wedding. Wealth may also provide a cultural signal of status and achievement, potentially conferring political power as well.

Future research should investigate these and other mediating channels to illuminate how accumulated wealth translates into advantages across domains and to reveal potential avenues for intervention. In addition to mediational analysis of net worth associations, another approach is to consider which component of wealth is likely to have the effect (Spilerman 2000). For example, Schneider (2011) hypothesizes that in the marriage market possessing an asset may be more important than the asset's value because asset ownership 
already signals marriageability. Likewise, Addo (2014) hypothesizes that credit card debt and education debt may be associated differently with union formation, due to the different financial structure and normativity of different types of debt, and Nau et al. (2015) consider how different types of debt are associated with fertility timing. Although the authors do not always find unequivocal support for their hypotheses, their approaches illustrate the importance both of conceptualizing wealth as a cultural marker, not just a stock of financial resources, and of empirically identifying how wealth produces effects by disaggregating net worth into theoretically relevant components.

\section{Wealth Determinants: Wealth as Outcome}

As noted above, wealth's feature as a stock variable complicates empirical analyses of the processes that produce it. As such, the literature exploring the determinants of wealth has focused primarily on estimating wealth differences by ascribed traits, such as age, race, gender, and social origins, although endogenous processes are sometimes used to explain these gaps. Now that broad consensus on the key ascribed traits determining wealth has emerged, we believe scholars' relative emphasis should shift to the causal pathways linking these characteristics to wealth accumulation. In this section, we first review the more tentative evidence on the causal pathways that produce wealth accumulation. We then describe the stronger evidence on the relationship between ascriptive characteristics and wealth attainment. Although this sequence may seem like putting the cart before the horse, it is necessary to first engage the evidence on the causal mechanisms behind wealth accumulation before evaluating research aimed at determining what processes can explain group-level differences in wealth. For example, we cannot evaluate research estimating the role of homeownership in producing race gaps in wealth without first engaging the evidence that homeownership is wealth-enhancing.

Processes of wealth accumulation-A key determinant of wealth is the flow of income into the household. As demonstrated above, wealth and income are strongly associated. The association with wealth is stronger at higher income and earnings levels (Barsky et al. 2002, Killewald 2013). Scholars often implicitly assume that causality flows from income to wealth, rather than the other way around, provided that asset income is excluded from income measures.

Next, we consider the role of portfolio allocation in wealth accumulation. Households with positive net worth must make decisions about the assets in which to invest their money. Particular assets, like home ownership, may affect wealth accumulation either through their rates of return, such as the appreciation of the home, or through behavioral effects, such as mortgage payments functioning as "forced savings." On the other hand, as described earlier, wealth facilitates the acquisition of particular assets, including homes. This potential for reverse causality challenges analyses geared at establishing effects of portfolio decisions on wealth accumulation.

Housing wealth constitutes the single largest component of wealth among middle-class families (Wolff 2016). As a result, the role of homeownership in the accumulation of wealth and reproduction of wealth disparities has attracted considerable scholarly attention. The 
wealth benefits of homeownership persist even after accounting for prior wealth levels and prior savings rates (Di et al. 2007, Killewald \& Bryan 2016). Wealth gains from homeownership and home appreciation rates vary by period, race, neighborhood, and region, yet homeownership appears to generate wealth for most households (Flippen 2004, Killewald \& Bryan 2016, Oliver \& Shapiro 2006).

Risky assets, such as businesses, stocks, and mutual funds, are assumed to have higher rates of return than either cash accounts or homeownership. Self-employment is associated with higher net worth (Altonji \& Doraszelski 2005, Menchik \& Jianakoplos 1997), as is stock ownership (Hurst et al. 1998). We view the evidence on the wealth effects of selfemployment and other asset choices as less conclusive than that for homeownership because less attention has been paid to accounting for selection. More research is needed to estimate the wealth benefits of different portfolio components relative not just to non-ownership but to ownership of alternative assets.

The same concerns of reverse causality surface when estimating the effect of family structure on wealth. Family structure may affect the flow of funds into the household as well as decisions about savings and portfolio composition, but, as we argued above, family structure is in turn shaped by wealth. Married couples accumulate substantially more wealth than unmarried individuals, women who are married only once have higher wealth than those who divorce and remarry, and in both cases differences are not entirely explained by other characteristics, including income (Addo \& Lichter 2013, Ruel \& Hauser 2013, Yamokoski \& Keister 2006, Zagorsky 2005). As with asset composition, research in this area has not fully engaged the causal challenges described above. Therefore, the evidence is currently not strong enough to confirm a causal effect of marriage on subsequent wealth accumulation.

An additional unresolved issue is the lack of consensus regarding whether wealth should be adjusted for family size to appropriately capture households' economic well-being. Marriage and cohabitation may be trivially associated with greater wealth as individuals pool assets. If households achieve economies of scale in wealth as in income - for example, two individuals do not need twice as expensive a house as a single person — these wealth gains are still meaningful, if mechanical. Future research is needed to establish both appropriate adjustments (if any) for household size and their consequences for the estimated wealth benefits of family structure.

Finally, we note that, similar to the evidence for wealth's effect on health, evidence for the causal effect of poor health and negative health shocks on wealth is mixed (Adams et al. 2003, Conley \& Thompson 2013, Hurd \& Kapteyn 2003, Wu 2003).

\section{Ascribed traits as wealth determinants: exogenous predictors}

Age: On average, wealth increases over the life course at least until about age 60 (DíazGiménez et al. 1997, Hurst et al. 1998, Wolff 1998) again illustrating wealth's position as a cumulative outcome. The strong association between age and wealth also reminds us that wealth's role as an indicator of socio-economic advantage may change over the life course. For example, if net worth is lower for some young adults than others because the former 
have invested in higher education, their current wealth position is likely not the best indicator of their long-term financial prospects. This is consistent with the relatively lower correlation between income and wealth we described previously: in young adulthood, investments in higher education may lead to high income before student loan debt is paid off. We encourage researchers modeling wealth outcomes in a sample heterogeneous by age to test the robustness of their results within different age groups.

Social Origins: The few available estimates of intergenerational wealth mobility suggest that the correlation of wealth across generations in the U.S. is roughly 0.3 to 0.4 , similar to the intergenerational persistence in other measures of socioeconomic attainment (Charles \& Hurst 2003, Conley \& Glauber 2008, Mulligan 1997, Pfeffer \& Killewald 2015). Strong intergenerational wealth persistence at the top of the distribution also characterizes more egalitarian Norway (Hansen 2014). Conceptualizing family more broadly, the wealth of grandparents is associated with own educational attainment and wealth, net of parental wealth (Hällsten \& Pfeffer Forthcoming, Pfeffer \& Killewald 2015), and extended family wealth is associated with education, transition to homeownership, and own wealth (Hall \& Crowder 2011, Prix \& Pfeffer Forthcoming).

Some of these associations may operate through direct transfers. The fraction of aggregate U.S. net worth attributable to inheritances or other transfers has been hotly debated, but it is typically estimated to exceed 50 percent when post-transfer appreciation is considered (Gale \& Scholz 1994, Kotlikoff \& Summers 1981, Wilhelm 2001). At the individual level, inheritances and inter vivos transfers are positively associated with net worth and wealth gains (Conley 2001a, Conley \& Ryvicker 2004, Hurst et al. 1998, Karagiannaki Forthcoming, McKernan et al. 2014, Menchik \& Jianakoplos 1997, Semyonov \& LewinEpstein 2013). However, in the U.S., direct transfers explain less than 20 percent of the intergenerational association in wealth positions (Charles \& Hurst 2003, Pfeffer \& Killewald 2015).

Intergenerational wealth similarity may also reflect indirect processes. As previously discussed, parental wealth facilitates offspring's educational outcomes. Education explains about a quarter of the intergenerational persistence in wealth (Pfeffer \& Killewald 2015), likely by supporting income persistence across generations (Charles \& Hurst 2003). Qualitative research emphasizes the importance parents place on wealth to improve their children's educational outcomes, particularly through neighborhood selection to access high-quality schools (Johnson 2006, Shapiro 2004).

Beyond parental wealth, other household characteristics may influence children's eventual wealth attainment. Having siblings is associated with lower adult wealth, possibly because parental resources of both money and time are diluted among offspring (Keister 2003a). Religious upbringing is also associated with wealth, with Jews accumulating more wealth than otherwise similar mainline Protestants and Catholics, who in turn accumulate more than conservative Protestants (Keister 2003b, 2007, 2008).

Education: Education is associated with greater wealth and more rapid wealth accumulation, net of income (Conley 2001a, Conley \& Ryvicker 2004, Keister 2003a,b, 
2004; Yamokoski \& Keister 2006). While the association between education and wealth accumulation is robust, the underlying mechanisms have received little attention. One possibility is that education is a proxy for prior income streams not captured by the current income measure, given the previously described challenges of modeling cumulative wealth with current income. Alternatively, education may directly affect wealth, perhaps due to the positive association between education and ownership of assets with higher risks and returns (Hanna et al. 2010, Kim et al. 2012).

Race, Ethnicity, and Nativity: Racial disparities in wealth in the U.S. are vast (Conley 1999, Oliver \& Shapiro 2006), with the median wealth of white households typically about 10 times that of black households and about 8 times that of Hispanic households; race disparities also increased during the Great Recession (Kochhar et al. 2011). In absolute terms, wealth disparities between whites and African-Americans are larger at higher points in the wealth distribution (Maroto 2016).

The race gap in income (or earnings) is a substantial contributor to the race gap in wealth (Barsky et al. 2002, Campbell \& Kaufman 2006, Menchik \& Jianakoplos 1997). Although blacks do not appear to save at lower rates than whites after adjusting for income (Conley 1999, Gittleman \& Wolff 2004), wealth disparities remain large even among households with similar incomes. Race differences in social origins, including family structure, the economic position of parents and extended family members, and inheritances, also contribute to the black-white wealth gap and to whites' higher rates of homeownership (Avery \& Rendall 2002, Charles \& Hurst 2002, Conley 2001a, Gittleman \& Wolff 2004, Hall \& Crowder 2011, McKernan et al. 2014, Menchik \& Jianakoplos 1997). Another contributing factor may be that affluent blacks provide financial assistance to family and friends in their networks at higher rates than their white counterparts (O'Brien 2012). Oliver and Shapiro (2006) refer to these various processes as the "sedimentation of racial inequality" - a history of discrimination and institutionalized racism that continues to disadvantage the wealth position of contemporary African-Americans. Even net of social origins, however, blacks experience higher rates of intergenerational downward wealth mobility (Conley \& Glauber 2008, Pfeffer \& Killewald 2015).

Although discrimination is notoriously difficult to identify in observational studies, prior research finds evidence consistent with discrimination against African-Americans in lending markets for homes, vehicles, and businesses (Blanchflower et al. 2003, Cavalluzzo \& Wolken 2005, Charles et al. 2008, Charles \& Hurst 2002, Oliver \& Shapiro 2006), including disproportionate rates of subprime mortgage loans among black households leading up to the Great Recession (Massey et al. 2016, Rugh 2015, Rugh et al. 2015). Neighborhood segregation further intensified African-Americans' vulnerability to subprime lending and home foreclosures (Hwang et al. 2015, Rugh et al. 2015, Rugh \& Massey 2010). We consider it likely that these forms of institutional discrimination, as well as residential segregation, directly contribute to the race gap in wealth. In particular, disproportionate wealth losses by black households during the Great Recession that cannot be explained by other factors (Kochhar et al. 2011, Pfeffer et al. 2013) may be partially attributable to excess lending costs and foreclosure rates driven by discrimination and segregation (Rugh 2015, Rugh et al. 2015). 
Despite the challenges of making causal claims regarding the role of endogenous pathways in producing the racial wealth gap, we believe there is sufficient evidence to conclude that housing markets contribute to it. Compared to whites, African-Americans have substantially lower rates of homeownership, transition to homeownership more slowly, own homes of lower values, have less housing equity, and exit homeownership at higher rates; these differences generally persist even after adjusting for race differences in other characteristics (Charles \& Hurst 2002, Flippen 2001, Keister 2000, 2004; Killewald \& Bryan 2016, Krivo \& Kaufman 2004, Sharp \& Hall 2014). Coupled with research on homeownership's wealth benefits, the evidence suggests that African-Americans are disadvantaged by their lower rates of homeownership. Whites also experience greater (absolute) wealth returns to homeownership (Killewald \& Bryan 2016), which may reflect slower appreciation by homes in minority neighborhoods (Flippen 2004, Oliver \& Shapiro 2006).

Race differences in asset portfolios, including business assets and self-employment, may contribute to the race gap in wealth as well (Altonji \& Doraszelski 2005, Conley 2001a, Gittleman \& Wolff 2004, Hurst et al. 1998, Keister 2000, Menchik \& Jianakoplos 1997, Oliver \& Shapiro 2006). In addition to homeownership, whites have higher rates of ownership of risky assets, such as stocks and businesses, net of other characteristics (Hurst et al. 1998; Keister 2000, 2004; Oliver \& Shapiro 2006). ${ }^{2}$ As discussed previously, the evidence for the effects of self-employment and portfolio composition on wealth is plagued by endogeneity concerns. As a result, we view the evidence on the role of portfolio choice as strongly suggestive and believe more research is needed to rigorously assess the implications of race differences in these factors for the race gap in wealth.

Race differences in marital histories may also contribute to the racial wealth gap (Addo \& Lichter 2013, Campbell \& Kaufman 2006), although endogeneity concerns are also at play here. Incarceration is associated with reduced wealth (Maroto 2015), suggesting that racial disparities in incarceration experience may contribute to the racial wealth gap. Compared to the research on homeownership and portfolio choice, these literatures are much thinner and additional analyses are needed to clarify the role of marriage and incarceration in generating racial wealth disparities.

African-Americans' wealth appears less responsive than whites' to their traits, including income, education, and marital history (Addo \& Lichter 2013, Altonji \& Doraszelski 2005, Campbell \& Kaufman 2006, Oliver \& Shapiro 2006). For earnings, a portion of the stronger association with wealth among whites is due to their greater representation toward the top of the earnings distribution, where the earnings-wealth association is stronger (Barsky et al. 2002). More research is needed to evaluate whether blacks' lower wealth returns to wealthenhancing traits is due primarily to blacks' lower wealth positions — where changes in factors such as income and asset ownership may generate modest wealth improvements or to race differences in wealth determinants that persist net of distributional differences. Again, this concern highlights the consequences of wealth operationalization decisions:

${ }^{2}$ Hanna et al. (2010) find that the race gap in ownership of risky assets is eliminated when a more flexible decomposition approach is used. 
African-Americans' wealth may change less with other traits than whites' in absolute terms, but perhaps not in proportional terms.

Although most research on race disparities in wealth focuses on blacks and whites, recent studies have also included other racial and ethnic groups. Like African-Americans, Hispanics are particularly disadvantaged relative to whites in absolute terms at higher points in the wealth distribution (Maroto 2016). Compared to whites, Hispanics have lower rates of homeownership, transition to homeownership more slowly, have higher rates of homeownership exit, possess less home equity than whites, and experience smaller wealth benefits from homeownership (Flippen 2001, Killewald \& Bryan 2016, Krivo \& Kaufman 2004). Of course, the Hispanic population in the United States is diverse, and wealth patterns may differ by ethnicity, national origin, and immigrant generation. For example, median net worth is higher among Cuban-Americans than among Mexican-Americans, who in turn hold more wealth than Puerto Ricans; Mexican-Americans who have resided in the U.S. for three generations or more accumulate more wealth by midlife, on average, than second-generation Mexican immigrants, and both groups exceed first-generation Mexican immigrants in median net worth (Keister et al. 2015).

As for African-Americans, Hispanic households had higher risk of exposure to subprime mortgage lending leading up to the Great Recession and higher foreclosure rates in the ensuing crisis (Rugh 2015). Segregation may have intensified these excess risks (Hwang et al. 2015), as did the timing and geographic settlement patterns of Hispanic immigrants, many of whom arrived in the Sand States (Arizona, California, Florida, and Nevada) and entered the suburban homeownership market at the peak of the housing boom (Rugh 2015). These factors may have contributed to Hispanics' disproportional wealth losses during the recession (Kochhar et al. 2011).

Asians hold, on average, less wealth than whites, but this gap increases after adjusting for other wealth-relevant traits: Asians' wealth is lower than expected, given their relatively advantaged positions in characteristics such as education, occupation, and income (Campbell \& Kaufman 2006).

In the U.S., variation in wealth by nativity status is modest compared to variation by raceethnicity and national origin (Hao 2004, 2007). Characteristics including class of admission, naturalization status, English language proficiency, having completed some education in the U.S., duration of residence in the U.S., and skin tone appear to contribute to variation in immigrants' net worth (Akresh 2011, Campbell \& Kaufman 2006, Painter II 2013, Painter II et al. 2016).

Gender: Among the unmarried, women's median wealth is less than men's (Chang 2010, Yamokoski \& Keister 2006). Income and employment differences play key roles in explaining the gap, although female-headed households' lower savings rates (Conley \& Ryvicker 2004) and women's investments in safer, lower-yield assets (Chang 2010, Ruel \& Hauser 2013) may also contribute. 
As described earlier, most surveys measure wealth at the household or couple level. Using German Socio-Economic Panel (SOEP) data, which tracks solely-held assets and the share owned of any jointly-held assets, Sierminska, Frick, and Grabka (2010) find that wealth gaps are largest in absolute terms among the married. The authors note that these findings question the assumption that wealth is a family-level characteristic, shared equally between spouses or partners. Using qualitative data on a U.S. sample, Chang (2010) documents that wives typically have less access to and control over marital wealth. Together, these findings suggest that research on the processes and practices shaping spouses' abilities to access financial assets and determine the use to which they are put would benefit if more household surveys clarified individual-level ownership of assets among married couples.

Macro-level determinants: Macro-economic circumstances, political institutions, and institutional structures also shape wealth levels and inequality. We have already touched on several plausibly salient macro factors, such as the rate of return relative to economic growth and the Great Recession. Institutionalized racism, including redlining and subprime lending, is also implicated in the race gap in wealth (Conley 1999, Massey \& Denton 1993, Oliver \& Shapiro 2006). As previously discussed, subprime lending is likely to affect the race gap in wealth via effects on lending costs and foreclosure rates.

Cross-country differences in the distribution of wealth are different from those based on income (Jäntti et al. 2008, Skopek et al. 2014). While socialist systems limit the accumulation of private wealth and thereby diminish the role of inheritance for asset accumulation (Szydlik 2004), more specific institutional and economic determinants of wealth levels and inequality are yet to be identified (Semyonov \& Lewin-Epstein 2013). Further cross-national comparative research is needed to explain these differences and establish how wealth patterns are shaped by macro-level factors, such as specific welfare state arrangements (e.g., public pension systems). Higher inflation rates constitute a broader economic factor influencing wealth inequality, by advantaging young, middle-class households' wealth position at the expense of older and richer households (Doepke \& Schneider 2006).

Policy: The topic of wealth accumulation among the poor is an active area of research and policy interest. Government transfer programs, including AFDC/TANF and Medicaid, may affect household wealth by reducing saving incentives and encouraging dissaving due to asset tests, or both, but evidence for these effects is mixed (Gruber \& Yelowitz 1999, Hurst \& Ziliak 2006, Sullivan 2006). Policies to increase savings incentives, such as matching contributions to savings accounts - which are sometimes contingent on using the savings for qualified expenditures like purchasing a home, starting a business, or financing education - may also spur asset-building among low-income households. However, whether these programs exert effects on net worth - rather than incentivizing the build-up of specific asset components at the expense of others - is less clear and these effects are small relative to the scope of U.S. wealth inequality (Duflo et al. 2006, Grinstein-Weiss et al. 2014, Mills et al. 2008, Schreiner \& Sherraden 2007).

Tax policies targeted at the other end of the wealth distribution, such as inheritance and wealth taxation (Bartels 2005, Beckert 2008), provide fertile grounds for further sociological 
inquiry. For example, the extent to which higher tax rates would directly reduce wealth inequality remains unclear (Looney \& Moore 2015, Piketty 2014).

Since the 1930s, active federal government intervention in the housing market has increased the supply of available mortgage capital. Through lending programs administered by the Federal Housing Administration (FHA) and the Veterans Administration (VA), the creation of a secondary mortgage market through Fannie and Freddie Mac, and the mortgage interest deduction, federal policy has expanded the proportion of Americans who could afford homeownership and likely increased the average size and value of homes purchased (for a review, see Shlay 2006).

\section{Part IV: Conclusion}

Since the $A R S$ reviews of the literature on wealth and wealth inequality by Keister and Moller (2000) and Spilerman (2000), wealth research has expanded considerably. A core argument advanced in these review pieces - that wealth is an independent and important dimension of social stratification - is now widely accepted. The intervening seventeen years have also witnessed a proliferation of data, including the introduction of net worth measures into new surveys, expanded panel time periods that permit the analysis of wealth accumulation across the life course and across generations, and the incorporation of administrative data and other non-survey sources to supplement survey-based analyses. Wealth research is no longer in its infancy, but perhaps in its adolescence: Despite the growth of scholarship and data, scholars in this area have not yet reached consensus on fundamental modeling and methodological decisions. We hope that this review makes the remaining challenges and stakes visible enough that, over the next decade, wealth research will move towards increased consensus on these decisions.

We close by outlining several avenues for future research that promise to enhance the sociological understanding of wealth:

\section{Qualitative research is needed to expand our understanding of wealth} generation and use. Although some qualitative studies have described couples' joint wealth management strategies (Chang 2010) and parents' aspirations to use wealth to benefit their children (Johnson 2006, Shapiro 2004), future research could further explore the processes and considerations that underlie households' savings and portfolio decisions.

2. Data availability has greatly expanded, but improvements are possible. The collection of individual-level net worth data may shed new light on gender and generational disparities in wealth, particularly within households. We also hope that the range of data sources evaluated for their asset data quality will expand, enabling researchers to make informed decisions about dataset reliability. Finally, using administrative data to study wealth inequality appears promising as long as broad data access is feasible.

3. Decisions about appropriately operationalizing net worth are not merely a methodological concern; they may significantly shape substantive conclusions. We encourage using transformations (e.g., percentiles) that permit 
coverage of the entire range of net worth values and that align with the analytic intent. For research questions involving the wealth consequences of family structure, scholars should assess their results' robustness to alternative family size adjustments. We currently know little about heterogeneity in wealth's determinants across the wealth distribution and this heterogeneity's consequences for group-level disparities in wealth.

4. Advances in establishing the causal role of endogenous processes (e.g., marriage, portfolio composition, self-employment, homeownership) are needed to illuminate the pathways generating wealth disparities by race, gender, and social origins. This research must engage conceptually and methodologically with the challenges of assessing the long-term wealth consequences of factors that may both determine and be determined by net worth.

5. Examining which components of wealth are particularly beneficial for other outcomes may illuminate the causal processes at work. Whether wealth is more valuable when it is liquid and accessible, whether its effects operate primarily through cultural signals rather than through the financial resources themselves, and whether schools and neighborhoods account for parental wealth's benefits are all questions ripe for future research.

6. Research on group disparities in wealth should continue to expand beyond black-white differences to include other racial/ethnic groups, nativity, and gender. This research will necessitate consideration of different processes, such as immigration experience or the gendered consequences of parenthood.

7. Comparative research can help reveal the macro-level determinants of wealth levels, intergenerational wealth mobility, and wealth inequality. Economists dominate research on alternative taxation policies and their consequences for the wealth distribution, but sociologists' expertise in studying political and social institutions should meaningfully inform these questions.

We consider wealth research to be at a particularly exciting juncture, having grown substantially over the last two decades and awaiting some important new advances. As with the transition to full adulthood, the development trajectory is difficult to predict. However, progress will undoubtedly continue given the rapidly expanding scope of data available and methodological advances. There is ample room and pressing need for increased scholarly attention to wealth in the twenty-first century, as wealth inequality reaches new heights in the U.S. and abroad.

\section{Acknowledgments}

We are grateful to Henry Gomory for research assistance, Lisa McAllister for editorial support, and Doug Massey for helpful comments on an earlier version of this manuscript.

\section{References}

Acemoglu D, Robinson JA. The rise and decline of general laws of capitalism. J. Econ. Perspect. 2015; 29(1):3-28. 
Adams P, Hurd MD, McFadden D, Merrill A, Ribeiro T. Healthy, wealthy, and wise? Tests for direct causal paths between health and socioeconomic status. J. Econom. 2003; 112(1):3-56.

Addo FR. Debt, cohabitation, and marriage in young adulthood. Demography. 2014; 51(5):1677-1701. [PubMed: 25267281]

Addo FR, Lichter DT. Marriage, marital history, and black - white wealth differentials among older women. J. Marriage Fam. 2013; 75(2):342-62.

Akresh IR. Wealth accumulation among U.S. immigrants: A study of assimilation and differentials. Soc. Sci. Res. 2011; 40(5):1390-1401.

Altonji JG, Doraszelski U. The role of permanent income and demographics in black/white differences in wealth. J. Hum. Resour. 2005; 40(1):1-30.

Attanasio OP, Hoynes HW. Differential mortality and wealth accumulation. J. Hum. Resour. 2000; 35(1):1-29.

Avery RB, Rendall MS. Lifetime inheritances of three generations of whites and blacks. Am. J. Sociol. 2002; 107(5):1300-1346.

Banks J, Muriel A, Smith JP. Disease prevalence, disease incidence, and mortality in the United States and in England. Demography. 2010; 47(S):S211-31. [PubMed: 21302425]

Barsky R, Bound J, Charles KK, Lupton JP. Accounting for the black-white wealth gap. J. Am. Stat. Assoc. 2002; 97(459):663-73.

Bartels LM. Homer gets a tax cut: Inequality and public policy in the American mind. Perspect. Polit. 2005; 3(1):15-31.

Beckert, J. Inherited Wealth. English. Princeton, NJ: Princeton University Press; 2008.

Blanchflower DG, Levine PB, Zimmerman DJ. Discrimination in the small-business credit market. Rev. Econ. Stat. 2003; 85(4):930-43.

Bond Huie SA, Krueger PM, Rogers RG, Hummer RA. Wealth, race, and mortality. Soc. Sci. Q. 2003; 84(3):667-84.

Boserup SH, Kopczuk W, Kreiner CT. The role of bequests in shaping wealth inequality: Evidence from Danish wealth records. Am. Econ. Rev. 2016; 106(5):656-61.

Bosworth, BP., Smart, R. CRR WP 2009 4. Center for Retirement Research at Boston College; Chestnut Hill, MA: 2009. Evaluating micro-survey estimates of wealth and saving.

Campbell LA, Kaufman RL. Racial differences in household wealth: Beyond black and white. Res. Soc. Stratif. Mobil. 2006; 24(2):131-52.

Cavalluzzo K, Wolken J. Small business loan turndowns, personal wealth, and discrimination. J. Bus. 2005; 78(6):2153-78.

Chang, ML. Shortchanged?: Why Women Have Less Wealth and What Can Be Done about It. New York, NY: Oxford University Press; 2010.

Charles KK, Hurst E. The transition to home ownership and the black-white wealth gap. Rev. Econ. Stat. 2002; 84(2):281-97.

Charles KK, Hurst E. The correlation of wealth across generations. J. Polit. Econ. 2003; 111(6):115582.

Charles KK, Hurst E, Stephens M Jr. Rates for vehicle loans: Race and loan source. Am. Econ. Rev. 2008; 98(2):315-20.

Conley, D. Being Black, Living in the Red?: Race, Wealth, and Social Policy in America. Berkeley, CA: University of California Press; 1999.

Conley D. Decomposing the black-white wealth gap: The role of parental resources, inheritance, and investment dynamics. Sociol. Inq. 2001a; 71(1):39-66.

Conley D. Capital for college: Parental assets and postsecondary schooling. Sociol. Educ. 2001b; 74(1):59-72.

Conley, D., Glauber, R. Wealth mobility and volatility in black and white. Center for American Progress; Washington, DC: 2008.

Conley D, Ryvicker M. The price of female headship?: Gender, inheritance and wealth accumulation in the United States. J. Income Distrib. 2004; 13(3-4):41-56.

Conley D, Thompson J. The effects of health and wealth shocks on retirement decisions. Fed. Reserve Bank St Louis Rev. 2013; 95(5):389-404. 
Curtin, RT., Juster, FT., Morgan, JN. Survey estimates of wealth: An assessment of quality. In: Lipsey, RE., Tice, HS., editors. The Measurement of Saving, Investment, and Wealth. Chicago, IL: University of Chicago Press; 1989. p. 473-552.

Czajka JL, Jacobson JE, Cody S. Survey estimates of wealth: A comparative analysis and review of the Survey of Income and Program Participation. Soc. Secur. Bull. 2003; 65(1):63-69.

Davies, JB., editor. Personal Wealth from a Global Perspective. New York, NY: Oxford University Press; 2008.

Devlin-Foltz S, Henriques A, Sabelhaus J. Is the U.S. retirement system contributing to rising wealth inequality? Russell Sage Found. J. Soc. Sci. 2016; 2(6):59-85.

Di ZX, Belsky E, Liu X. Do homeowners achieve more household wealth in the long run? J. Hous. Econ. 2007; 16(3-4):274-90.

Di ZX, Liu X. The importance of wealth and income in the transition to homeownership. Cityscape. 2007; 9(2):137-51.

Díaz-Giménez J, Quadrini V, Ríos-Rull J-V. Dimensions of inequality: Facts on the U.S. distributions of earnings, income, and wealth. Fed. Reserve Bank Minneap. Q. Rev. 1997; 21(2):3-21.

DiNardo J, Fortin NM, Lemieux T. Labor market institutions and the distribution of wages, 19731992: A semiparametric approach. Econometrica. 1996; 64(5):1001-44.

Doepke M, Schneider M. Inflation and the redistribution of nominal wealth. J. Polit. Econ. 2006; 114(6):1069-97.

Doren C, Grodsky E. What skills can buy: Transmission of advantage through cognitive and noncognitive skills. Sociol. Educ. 2016; 89(4):321-42. [PubMed: 28337046]

Duflo E, Gale W, Liebman J, Orszag P, Saez E. Saving incentives for low- and middle-income families: Evidence from a field experiment with H\&R Block. Q. J. Econ. 2006; 121(4):1311-46.

Ekerdt DJ, Hackney JK. Workers' ignorance of retirement benefits. The Gerontologist. 2002; 42(4): 543-51. [PubMed: 12145382]

Fairlie RW, Krashinsky HA. Liquidity constraints, household wealth, and entrepreneurship revisited. Rev. Income Wealth. 2012; 58(2):279-306.

Firpo S, Fortin NM, Lemieux T. Unconditional quantile regressions. Econometrica. 2009; 77(3):95373.

Flippen C. Unequal returns to housing investments? A study of real housing appreciation among black, white, and Hispanic households. Soc. Forces. 2004; 82(4):1523-51.

Flippen CA. Racial and ethnic inequality in homeownership and housing equity. Sociol. Q. 2001; 42(2):121-49.

Friedline T, Masa RD, Chowa GAN. Transforming wealth: Using the inverse hyperbolic sine (IHS) and splines to predict youth's math achievement. Soc. Sci. Res. 2015; 49:264-87. [PubMed: 25432618]

Gale WG, Scholz JK. Intergenerational transfers and the accumulation of wealth. J. Econ. Perspect. 1994; 8(4):145-60.

Gittleman M, Wolff EN. Racial differences in patterns of wealth accumulation. J. Hum. Resour. 2004; 39(1):193-227.

Grinstein-Weiss M, Shanks TRW, Beverly SG. Family assets and child outcomes: Evidence and directions. Future Child. 2014:147-70. [PubMed: 25518707]

Gruber J, Yelowitz A. Public health insurance and private savings. J. Polit. Econ. 1999; 107(6):124974.

Hall M, Crowder K. Extended-family resources and racial inequality in the transition to homeownership. Soc. Sci. Res. 2011; 40(6):1534-46. [PubMed: 23564980]

Hällsten M, Pfeffer FT. Grand advantage: Family wealth and grandchildren's educational attainment in Sweden. Am. Sociol. Rev. Forthcoming.

Hanna SD, Wang C, Yuh Y. Racial/ethnic differences in high return investment ownership: A decomposition analysis. J. Financ. Couns. Plan. 2010; 21(2):44-59.

Hansen MN. Self-made wealth or family wealth? Changes in intergenerational wealth mobility. Soc. Forces. 2014; 93(2):457-81.

Hao L. Wealth of immigrant and native-born Americans. Int. Migr. Rev. 2004; 38(2):518-46. 
Hao, L. Color Lines, Country Lines: Race, Immigration, and Wealth Stratification in America. New York, NY: Russell Sage Foundation; 2007.

Hauser RM, Weir D. Recent developments in longitudinal studies of aging in the United States. Demography. 2010; 47(S):S111-30. [PubMed: 21302430]

Hurd M, Kapteyn A. Health, wealth, and the role of institutions. J. Hum. Resour. 2003; 38(2):386-415.

Hurst E, Luoh MC, Stafford FP. The wealth dynamics of American families, 1984-94. Brook. Pap. Econ. Act. 1998; 1998(1):267-337.

Hurst E, Lusardi A. Liquidity constraints, household wealth, and entrepreneurship. J. Polit. Econ. 2004; 112(2):319-47.

Hurst E, Ziliak JP. Do welfare asset limits affect household saving? Evidence from welfare reform. J. Hum. Resour. 2006; 41(1):46-71.

Hwang J, Hankinson M, Brown KS. Racial and spatial targeting: Segregation and subprime lending within and across metropolitan areas. Soc. Forces. 2015; 93(3):1081-1108.

Jäntti, M., Sierminska, E., Smeeding, TM. How is Household Wealth Distributed? Evidence from the Luxembourg Wealth Study. In: OECD. , editor. Growing Unequal? Income Distribution and Poverty in OECD Countries. Organization for Economic Co-Operation and Development; 2008. p. 253-78.

Jez SJ. The differential impact of wealth versus income in the college-going process. Res. High. Educ. 2014; 55(7):710-34.

Johnson, HB. The American Dream and the Power of Wealth?: Choosing Schools and Inheriting Inequality in the Land of Opportunity. New York, NY: Routledge; 2006.

Juster FT, Smith JP, Stafford F. The measurement and structure of household wealth. Labour Econ. 1999; 6(2):253-75.

Karagiannaki E. The impact of inheritance on the distribution of wealth: Evidence from Great Britain. Rev. Income Wealth. Forthcoming.

Keister LA. Race and wealth inequality: The impact of racial differences in asset ownership on the distribution of household wealth. Soc. Sci. Res. 2000; 29(4):477-502.

Keister LA. Sharing the wealth: The effect of siblings on adults' wealth ownership. Demography. 2003a; 40(3):521-42. [PubMed: 12962061]

Keister LA. Religion and wealth: The role of religious affiliation and participation in early adult asset accumulation. Soc. Forces. 2003b; 82(1):175-207.

Keister LA. Race, family structure, and wealth: The effect of childhood family on adult asset ownership. Sociol. Perspect. 2004; 47(2):161-87.

Keister LA. Upward wealth mobility: Exploring the Roman Catholic advantage. Soc. Forces. 2007; 85(3):1195-1225.

Keister LA. Conservative Protestants and wealth: How religion perpetuates asset poverty. Am. J. Sociol. 2008; 113(5):1237-71.

Keister LA. The one percent. Annu. Rev. Sociol. 2014; 40:347-67.

Keister LA, Moller S. Wealth inequality in the United States. Annu. Rev. Sociol. 2000; 26:63-81.

Keister LA, Vallejo JA, Borelli EP. Mexican American mobility: Early life processes and adult wealth ownership. Soc. Forces. 2015; 93(3):1015-46.

Killewald A. Return to Being Black, Living in the Red: A race gap in wealth that goes beyond social origins. Demography. 2013; 50(4):1177-95. [PubMed: 23658068]

Killewald A, Bearak J. Is the motherhood penalty larger for low-wage women? A comment on quantile regression. Am. Sociol. Rev. 2014; 79(2):350-57.

Killewald A, Bryan B. Does your home make you wealthy? RSF Russell Sage Found. J. Soc. Sci. 2016; 2(6):110-28.

Kim EJ, Hanna SD, Chatterjee S, Lindamood S. Who among the elderly owns stocks? The role of cognitive ability and bequest motive. J. Fam. Econ. Issues. 2012; 33(3):338-52.

Kochhar, R., Fry, R., Taylor, P. Wealth gaps rise to record highs between whites, blacks and Hispanics. Pew Research Center; Washington, DC: 2011.

Kopczuk W, Saez E. Top wealth shares in the United States, 1916-2000: Evidence from estate tax returns. Natl. Tax J. 2004; 57(2):445-87. 
Kotlikoff LJ, Summers LH. The role of intergenerational transfers in aggregate capital accumulation. J. Polit. Econ. 1981; 89(4):706-32.

Krivo LJ, Kaufman RL. Housing and wealth inequality: Racial-ethnic differences in home equity in the United States. Demography. 2004; 41(3):585-605. [PubMed: 15461016]

Lerman DL, Mikesell JJ. Rural and urban poverty: An income/net worth approach. Policy Study Rev. 1988; 7(4):765-81.

Looney, A., Moore, KB. Finance and Economics Discussion Series 2015-058. Board of Governors of the Federal Reserve System; Washington D.C.: 2015. Changes in the distribution of after-tax wealth: Has income tax policy increased wealth inequality?

Lovenheim MF, Reynolds CL. The effect of housing wealth on college choice: Evidence from the housing boom. J. Hum. Resour. 2013; 48(1):1-35.

Maroto M. Growing farther apart: Racial and ethnic inequality in household wealth across the distribution. Sociol. Sci. 2016; 3:801-24.

Maroto ML. The absorbing status of incarceration and its relationship with wealth accumulation. J. Quant. Criminol. 2015; 31(2):207-36.

Massey, DS., Denton, NA. American Apartheid: Segregation and the Making of the Underclass. Cambridge, MA: Harvard University Press; 1993.

Massey DS, Rugh JS, Steil JP, Albright L. Riding the stagecoach to hell: A qualitative analysis of racial discrimination in mortgage lending. City Community. 2016; 15(2):118-36.

McKernan S-M, Ratcliffe C, Simms M, Zhang S. Do racial disparities in private transfers help explain the racial wealth gap? New evidence from longitudinal data. Demography. 2014; 51(3):949-74. [PubMed: 24781650]

Menchik PL, Jianakoplos NA. Black-white wealth inequality: Is inheritance the reason? Econ. Inq. 1997; 35(2):428-42.

Mills G, Gale WG, Patterson R, Engelhardt GV, Eriksen MD, Apostolov E. Effects of individual development accounts on asset purchases and saving behavior: Evidence from a controlled experiment. J. Public Econ. 2008; 92(5-6):1509-30.

Mulligan, CB. Parental Priorities and Economic Inequality. Chicago, IL: University of Chicago Press; 1997.

Nau M, Dwyer RE, Hodson R. Can't afford a baby? Debt and young Americans. Res. Soc. Stratif. Mobil. 2015; 42:114-22. [PubMed: 28090131]

O'Brien RL. Depleting capital? Race, wealth and informal financial assistance. Soc. Forces. 2012; 91(2):375-95.

Oliver, ML., Shapiro, TM. Black Wealth, White Wealth?: A New Perspective on Racial Inequality. New York, NY: Routledge; 2006.

Orr AJ. Black-white differences in achievement: The importance of wealth. Sociol. Educ. 2003; 76(4): 281-304.

Painter MA II. Immigrant and native financial well-being: The roles of place of education and race/ ethnicity. Soc. Sci. Res. 2013; 42(5):1375-89. [PubMed: 23859737]

Painter MA II, Holmes MD, Bateman J. Skin tone, race/ethnicity, and wealth inequality among new immigrants. Soc. Forces. 2016; 94(3):1153-85.

Pence KM. The role of wealth transformations: An application to estimating the effect of tax incentives on saving. BE J. Econ. Anal. Policy. 2006; 5(1) Article 20.

Pfeffer, FT. Status attainment and wealth in the United States and Germany. In: Smeeding, TM.Erikson, R., Jäntti, M., editors. Persistence, Privilege, and Parenting. The Comparative Study of Intergenerational Mobility. New York, NY: Russell Sage Foundation; 2011. p. 109-37.

Pfeffer FT, Danziger S, Schoeni RF. Wealth disparities before and after the Great Recession. Ann. Am. Acad. Pol. Soc. Sci. 2013; 650:98-123. [PubMed: 25332508]

Pfeffer, FT., Killewald, A. Population Studies Center Research Report. Population Studies Center, University of Michigan; Ann Arbor, MI: 2015. How rigid is the wealth structure and why? Interand multigenerational associations in family wealth; p. 15-845.

Pfeffer FT, Schoeni R. How wealth inequality shapes our future. Russell Sage Found. J. Soc. Sci. 2016; $2(6): 2-22$ 
Pfeffer FT, Schoeni RF, Kennickell A, Andreski P. Measuring wealth and wealth inequality: Comparing two U.S. surveys. J. Econ. Soc. Meas. 2016; 41(2):103-20. [PubMed: 27942105]

Piketty, T. Capital in the Twenty-First Century. Cambridge, MA: The Belknap Press of Harvard University Press; 2014.

Prix, I., Pfeffer, FT. Does Donald need Uncle Scrooge? Extended family's wealth and children's educational attainment in the United States. In: Erola, J., Kilpi-Jakonen, E., editors. Intergenerational Cumulative Disadvantage and Resource Compensation. Cheltenham, UK: Edward Elgar; Forthcoming

Robins JM, Hernán MÁ, Brumback B. Marginal structural models and causal inference in epidemiology. Epidemiology. 2000; 11(5):550-60. [PubMed: 10955408]

Ruel E, Hauser RM. Explaining the gender wealth gap. Demography. 2013; 50(4):1155-76. [PubMed: 23264038]

Rugh JS. Double jeopardy: Why Latinos were hit hardest by the US foreclosure crisis. Soc. Forces. 2015; 93(3):1139-84.

Rugh JS, Albright L, Massey DS. Race, space, and cumulative disadvantage: A case study of the subprime lending collapse. Soc. Probl. 2015; 62(2):186-218. [PubMed: 27478254]

Rugh JS, Massey DS. Racial segregation and the American foreclosure crisis. Am. Sociol. Rev. 2010; 75(5):629-51. [PubMed: 25308973]

Saez E, Zucman G. Wealth inequality in the United States since 1913: Evidence from capitalized income tax data. Q. J. Econ. 2016; 131(2):519-78.

Schneider D. Wealth and the marital divide. Am. J. Sociol. 2011; 117(2):627-67. [PubMed: 22268248]

Schreiner, M., Sherraden, M. Can the Poor Save? Saving \& Asset Building in Individual Development Accounts. New Brunswick, NJ: Transaction Publishers; 2007.

Semyonov M, Lewin-Epstein N. Ways to richness: Determination of household wealth in 16 countries. Eur. Sociol. Rev. 2013; 29(6):1134-48.

Semyonov M, Lewin-Epstein N, Maskileyson D. Where wealth matters more for health: The wealthhealth gradient in 16 countries. Soc. Sci. Med. 2013; 81:10-17. [PubMed: 23422055]

Shapiro, TM. The Hidden Cost of Being African American?: How Wealth Perpetuates Inequality. New York, NY: Oxford University Press; 2004.

Sharp G, Hall M. Emerging forms of racial inequality in homeownership exit, 1968-2009. Soc. Probl. 2014; 61(3):427-47.

Shlay AB. Low-income homeownership: American dream or delusion? Urban Stud. 2006; 43(3):51131.

Sierminska EM, Frick JR, Grabka MM. Examining the gender wealth gap. Oxf. Econ. Pap. 2010; 62(4):669-90.

Skopek N, Buchholz S, Blossfeld H-P. National patterns of income and wealth inequality. Int. J. Comp. Sociol. 2014; 55(6):463-88.

Smith JP. The impact of socioeconomic status on health over the life-course. J. Hum. Resour. 2007; 42(4):739-64.

Soskice D. Capital in the Twenty-First Century. A critique. Br. J. Sociol. 2014; 65(4):650-66. [PubMed: 25516344]

Spilerman S. Wealth and stratification processes. Annu. Rev. Sociol. 2000; 26:497-524.

Spilerman S, Wolff F-C. Parental wealth and resource transfers: How they matter in France for home ownership and living standards. Soc. Sci. Res. 2012; 41(2):207-23. [PubMed: 23017746]

Sullivan JX. Welfare reform, saving, and vehicle ownership. J. Hum. Resour. 2006; 41(1):72-105.

Szydlik M. Inheritance and inequality: Theoretical reasoning and empirical evidence. Eur. Sociol. Rev. 2004; 20(1):31-45.

Vespa J. Union formation in later life: Economic determinants of cohabitation and remarriage among older adults. Demography. 2012; 49(3):1103-25. [PubMed: 22549155]

Wilhelm, MO. The role of intergenerational transfers in spreading asset ownership. In: Shapiro, TM., Wolff, EN., editors. Assets for the Poor: The Benefits of Spreading Asset Ownership. New York, NY: Russell Sage Foundation; 2001. p. 132-61. 
Wolff EN. Recent trends in the size distribution of household wealth. J. Econ. Perspect. 1998; 12(3): 131-50.

Wolff, EN. The Transformation of the American Pension System: Was It Beneficial for Workers?. Kalamazoo, MI: W.E. Upjohn Institute; 2011.

Wolff EN. U.S. pensions in the 2000s: The lost decade? Rev. Income Wealth. 2015; 61(4):599-629.

Wolff EN. Household wealth trends in the United States, 1962 to 2013: What happened over the Great Recession? Russell Sage Found. J. Soc. Sci. 2016; 2(6):24-43.

Wu S. The effects of health events on the economic status of married couples. J. Hum. Resour. 2003; 38(1):219-30.

Yamokoski A, Keister LA. The wealth of single women: Marital status and parenthood in the asset accumulation of young baby boomers in the United States. Fem. Econ. 2006; 12(1-2):167-94.

Yeung WJ, Conley D. Black-white achievement gap and family wealth. Child Dev. 2008; 79(2):30324. [PubMed: 18366425]

Zagorsky JL. Marriage and divorce's impact on wealth. J. Sociol. 2005; 41(4):406-24. 
0.75

0.70

0.65

0.60

0.55

0.50

0.45

0.40

0.35

0.30

0.25

0.20

0.15

0.10

0.05

0.00

PSID lyr

PSID 10yr

SCF

Raw Top-Coded

\section{Log Inverse Hyperbolic Sine}

- Percentiles

Figure 1.

Wealth-income correlations by survey and specification (2013)

Note: Data are from the Panel Study of Income Dynamics (PSID) and the Survey of Consumer Finances (SCF). The first block of PSID correlations is based on a single year (analogous to the SCF), while the second block averages income measures over as many reports as are available in a ten-year span. PSID data are aggregated from the family to the household unit level to make estimates comparable to the SCF. Analytic samples are restricted to households with a household head aged 25 to 64. 


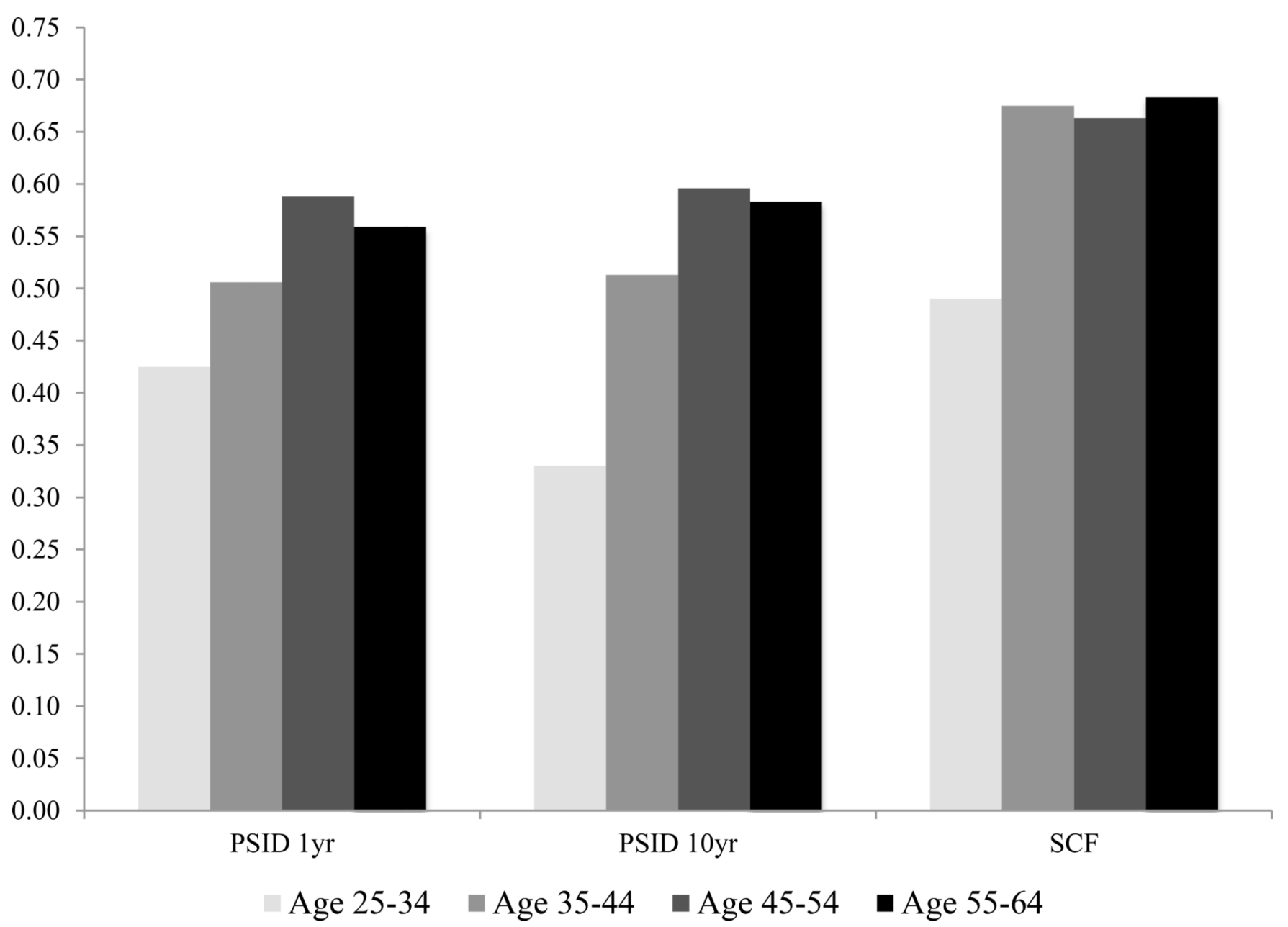

Figure 2.

Wealth-income correlations by survey and age (2013, percentiles)

Note: Data are from the Panel Study of Income Dynamics (PSID) and the Survey of Consumer Finances (SCF). The first block of PSID correlations is based on a single year (analogous to the SCF), while the second block averages income measures over as many reports as are available in a ten-year span. PSID data are aggregated from the family to the household unit level to make estimates comparable to the SCF. Analytic samples are restricted to households with a household head aged 25 to 64 . 


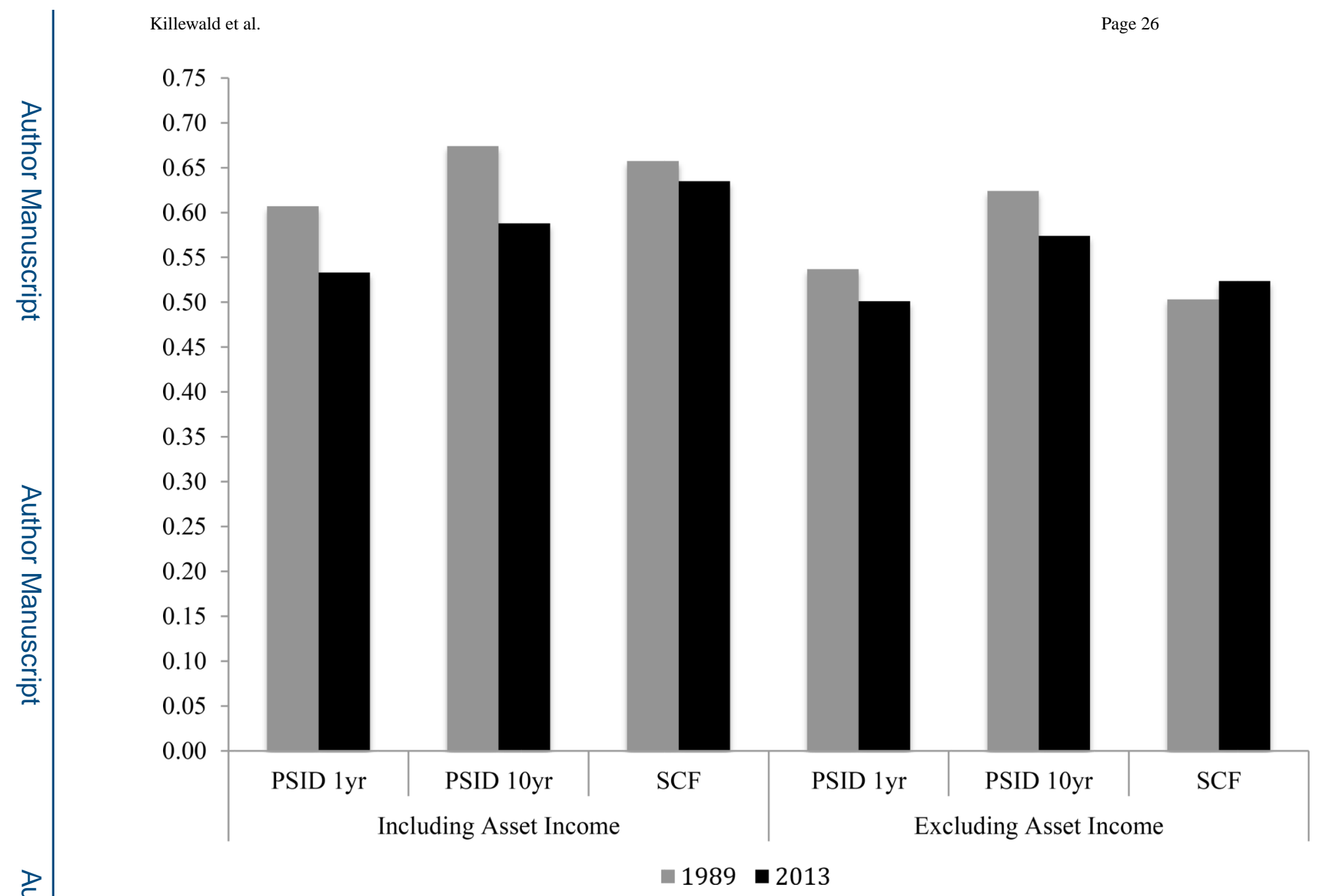

Figure 3.

Wealth-income correlations by survey, year, and income type (percentiles)

Note: Data are from the Panel Study of Income Dynamics (PSID) and the Survey of Consumer Finances (SCF). The first block of PSID correlations is based on a single year (analogous to the SCF), while the second block averages income measures over as many reports as are available in a ten-year span. PSID data are aggregated from the family to the household unit level to make estimates comparable to the SCF. Analytic samples are restricted to households with a household head aged 25 to 64 . 


\section{을

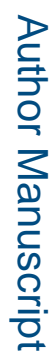

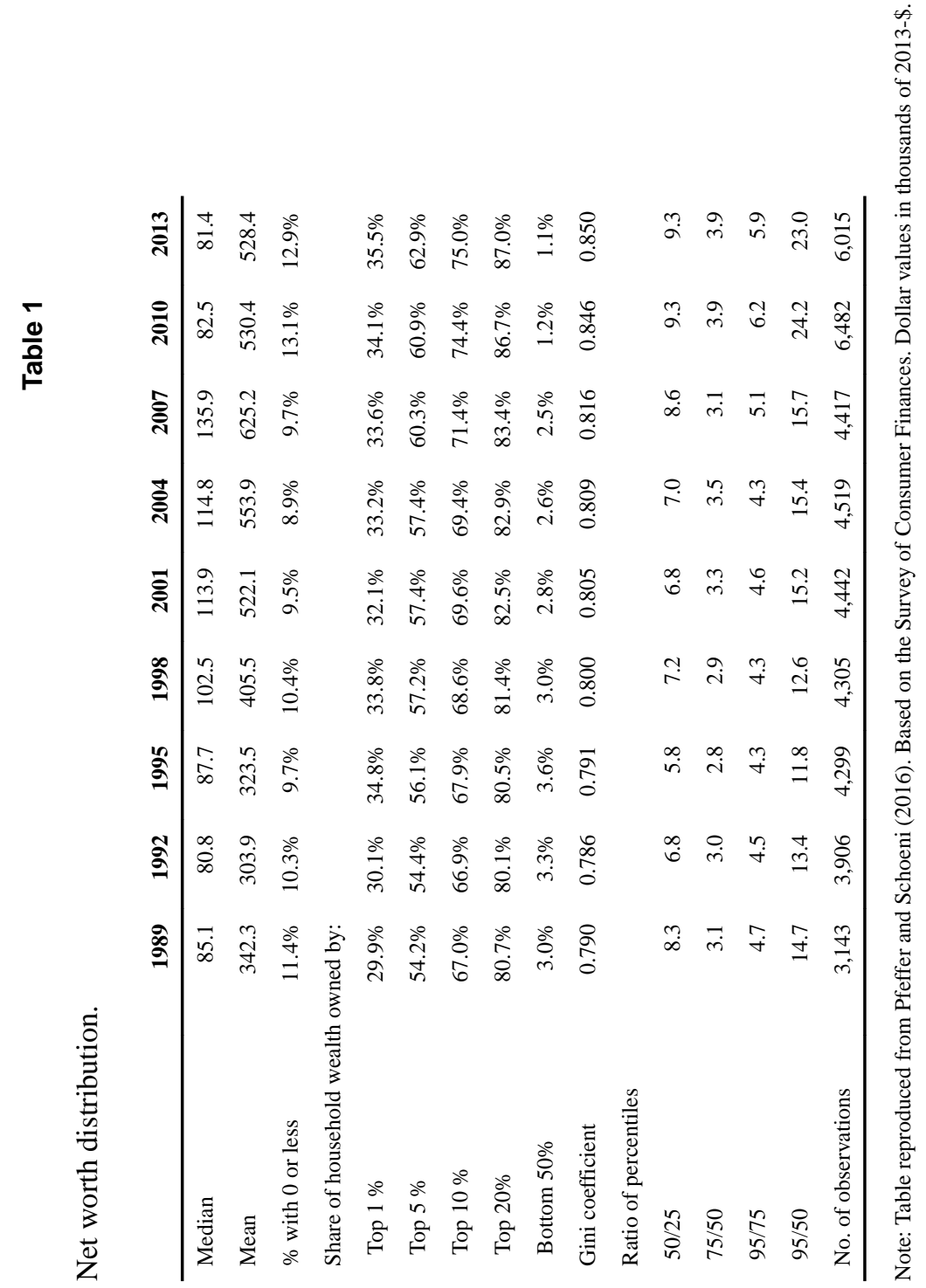

Annu Rev Sociol. Author manuscript; available in PMC 2018 July 01. 


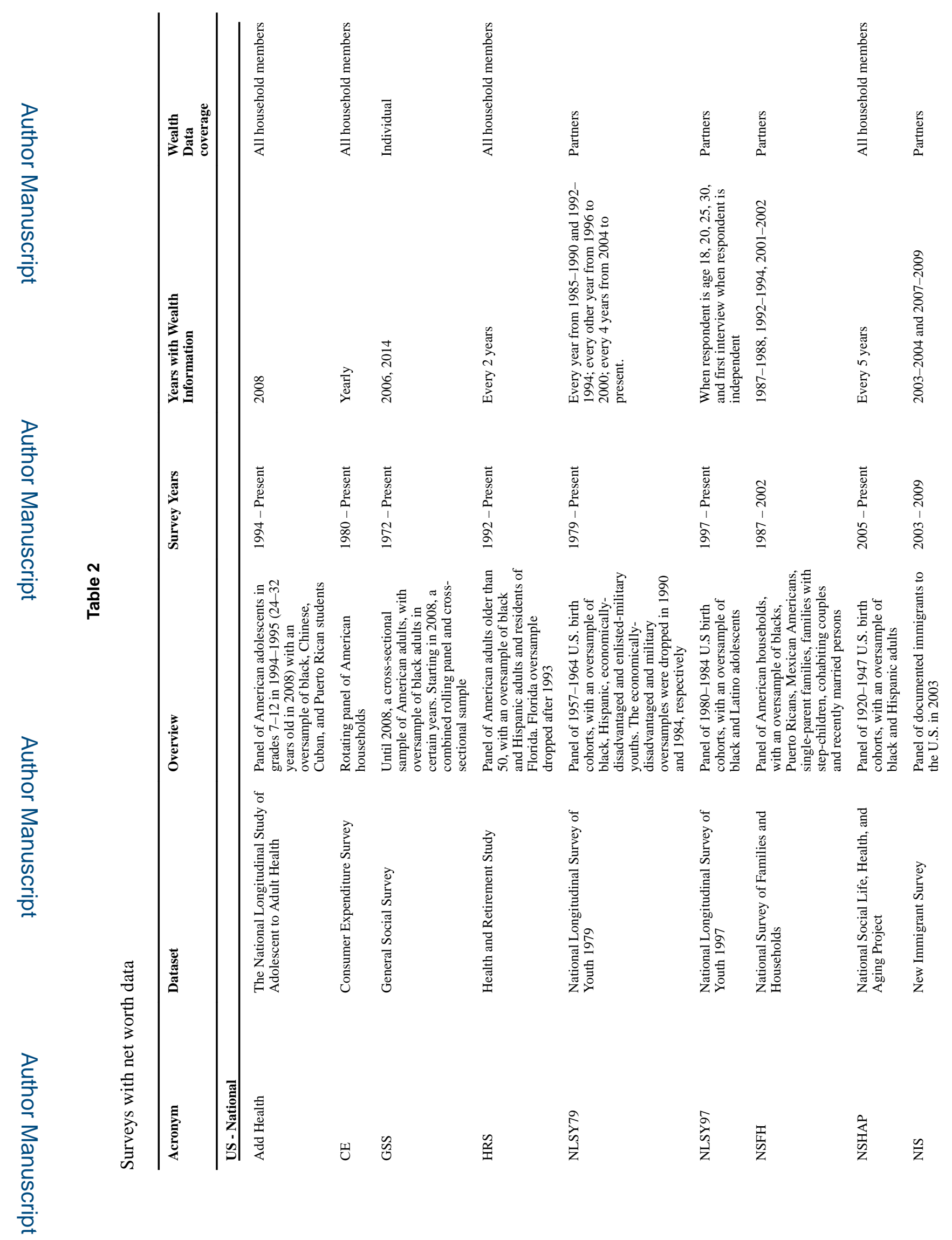

Annu Rev Sociol. Author manuscript; available in PMC 2018 July 01. 
Killewald et al.

Page 29

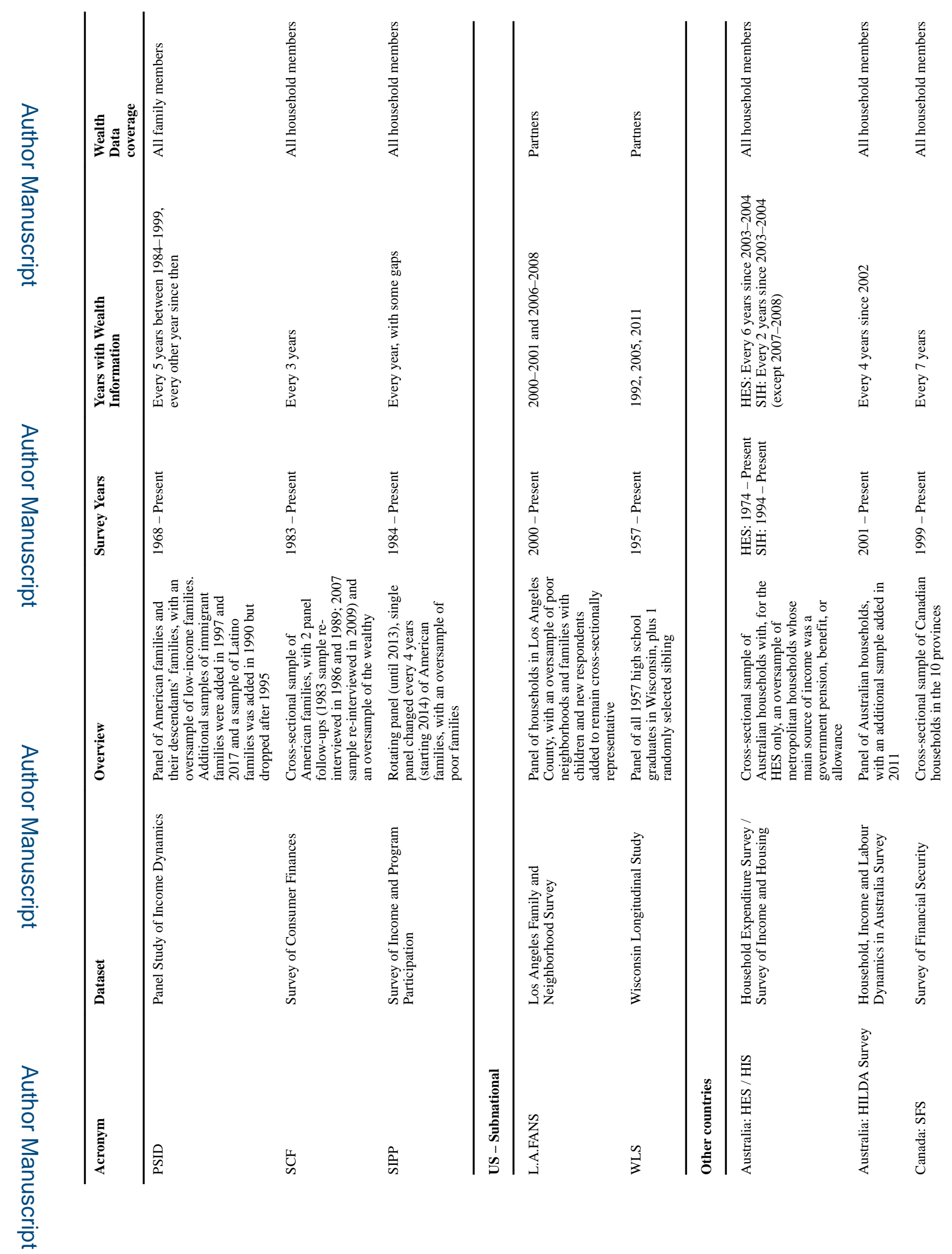

Annu Rev Sociol. Author manuscript; available in PMC 2018 July 01. 
Killewald et al.

Page 30

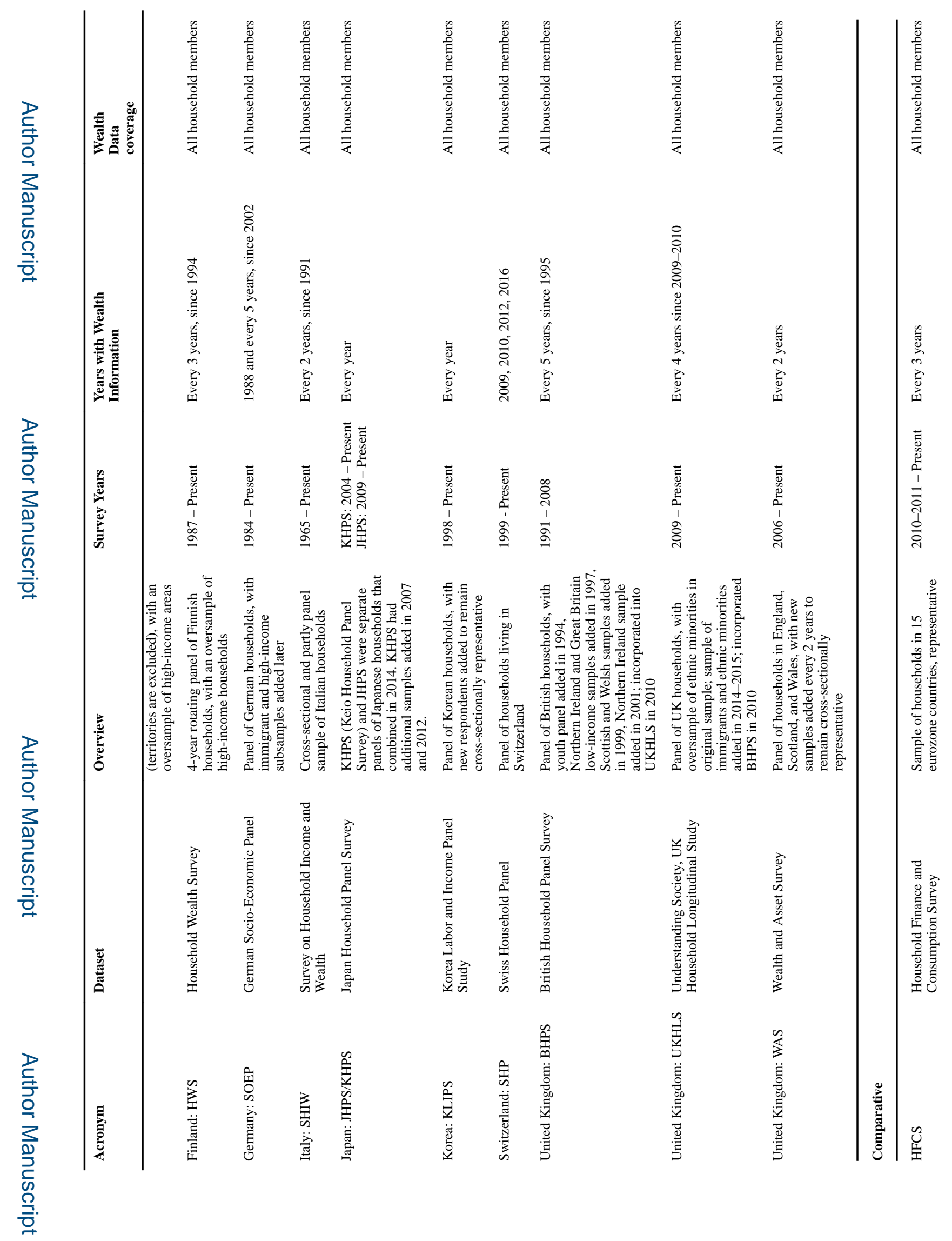

Annu Rev Sociol. Author manuscript; available in PMC 2018 July 01. 


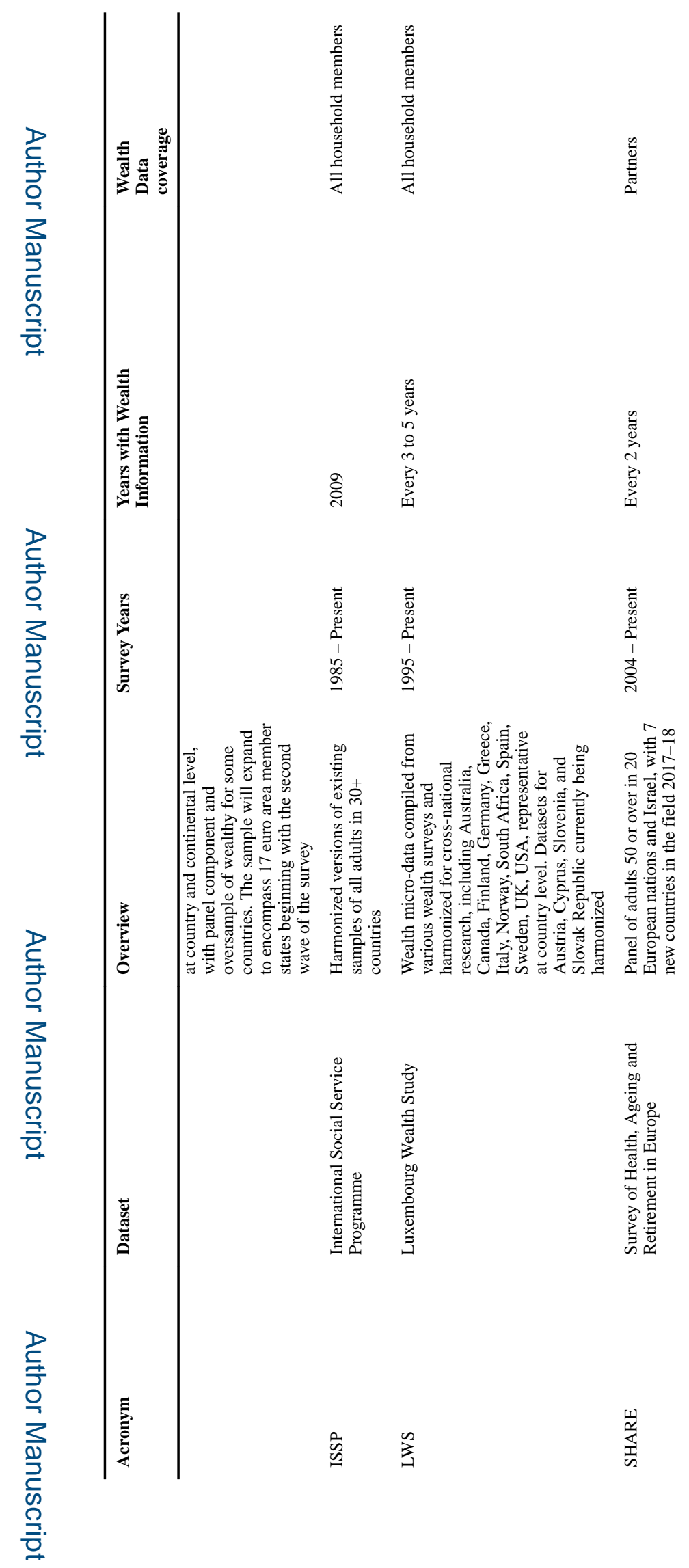

Annu Rev Sociol. Author manuscript; available in PMC 2018 July 01. 